\title{
PERBEDAAN HASIL BELAJAR INSTALASI PENERANGAN LISTRIK ANTARA SISWA YANG DIAJAR DENGAN MODEL PEMBELAJARAN BERBASIS MASALAH DENGAN SISWA YANG DIAJAR DENGAN MODEL PEMBELAJARAN EKSPOSITORI
}

\author{
Binnaro Hutahaean dan Marsangkap Silitonga \\ (Guru SMKN 1 Kepulauan Mentawai dan Dosen Jurusan Pendidikan Teknik Elektro)
}

\begin{abstract}
ABSTRAK
Penelitian ini bertujuan untuk mengetahui perbedaan hasil belajar instalasi penerangan listrik banguna sederhana antara siswa yang diajarkan dengan model pembelajaran berbasis masalah dengan siswa yang diajarkan dengan model pembelajaran ekspositori. Penelitian dilakukan pada siswa kelas XI program keahlian teknik instalasi tenaga listrik (TITL) SMK Negeri 2 Siatas Barita Tapanuli Utara pada tahun pelajaran 2014/2015. Populasi penelitian terdiri atas dua kelas, yang semuanya menjadi sampel. Hasil pengundian menempatkan kelas $\mathrm{XI}_{\text {TITL2 }}$ dengan 30 siswa sebagai kelas eksperimen yang diajar dengan model pembelajaran berbasis masalah sedangkan kelas $\mathrm{XI}_{\text {TITL1 }}$ dengan 28 siswa sebagai kelas kontrol yang diajar dengan model pembelajaran ekspositori.Metode penelitian adalah eksperimen dengan rancangan "Randomized Control Group Posttest Only Design". Data penelitian dijaring dengan tes, menggunakan instrumen berbentuk tes objektif pilihan berganda dengan lima pilihan jawaban. Instrumen tes digunakan setelah melalui ujicoba untuk mengetahui validitasnya dan reliabilitasnya Ujicoba instrumen mengasilkan 22 butir soal yang valid dengan koefisien reliabilitas sebesar 0,703. Hipotesis penelitian diuji dengan analisis statistik uji-t, yang dilakukan setelah memenuhi uji persyaratan analisis yaitu uji normalitas dan uji homogenitas. Hasil belajar instalasi penerangan listrik bangunan sederhana siswa yang diajar dengan model pembelajaran berbasis masalah memiliki skor rata-rata 15,93 dengan standar deviasi sebesar 1,78; sedangkan siswa yang dengan model pembelajaran ekspositori memiliki skor rata-rata 13,86 dengan standart deviasi sebesar 1,89. Dengan menggunakan analisis statistik uji-t diperoleh t-hitung sebesar 16,386 sedangkan harga t-tabel untuk $\alpha=0,05$ dan derajat kebebasan 56 adalah 2,003. Dengan demikian disimpulkan bahwa hasil belajar instalasi penerangan listrik bangunan sederhana siswa yang diajar dengan model pembelajaran berbasis masalah lebih tinggi dibandingkan dengan hasil belajar siswa yang diajar dengan model pembelajaran ekspositori.
\end{abstract}

\section{Kata kunci: Pembelajaran Berbasis Masalah, Hasil Belajar, Instalasi Penerangan.}

\section{PENDAHULUAN}

Sekolah Menengah Kejuruan (SMK) memiliki peranan yang sangat penting dalam meningkatkan kualitas Sumber Daya Manusia. SMK terus berusaha menghasilkan lulusan yang benar-benar mempunyai skill atau kemampuan dalam bidangnya masingmasing. Untuk mencapai hal tersebut dibutuhkan pembelajaran yang tepat dan efektif untuk memberikan hasil belajar yang diharapkan. Hasil belajar siswa merupakan hasil dari suatu proses yang di dalamnya terdapat sejumlah faktor yang saling mempengaruhi antara lain: (1) faktor eksternal (faktor yang berasal dari luar diri siswa) seperti : faktor keluarga, lingkungan, sekolah; serta (2) Faktor internal (faktor yang berasal dari dalam diri siswa), seperti : minat, bakat, motivasi. (Slameto, 2003: 54). Permasalahan yang kerap terjadi dan tidak diinginkan adalah hasil belajar yang kurang memuaskan. Hasil belajar belum mencapai standar Kriteria Kentuntasan Minimal (KKM) yang ditetapkan sekolah. Pembelajaran yang ini digunakan umumnya masih pembelajaran ekspositori, di mana guru menerangkan dan siswa mendengarkan dan mencatat. Keterlibatan siswa dalam 
pembelajaran bersifat pasif dan lebih banyak menunggu sajian dari guru.

Model pembelajaran menjadi satu faktor eksternal yang mempengaruhi hasil belajar. Guru perlu mengembangkan potensi siswa secara optimal melalui model pembelajaran yang tepat. Oleh karena itu guru perlu menguasai model pembelajaran dan menerapkannya di dalam proses pembelajaran. Model pembelajaran adalah suatu kegiatan yang harus dikerjakan guru dan siswa agar tujuan pembelajaran dapat dicapai secara efektif dan efesien. Model pembelajaran adalah suatu set materi dan prosedur pembelajaran yang digunakan secara bersama-sama untuk menimbulkan hasil belajar pada siswa (Sanjaya, 2010;126). Dalam memilih model pembelajaran, guru harus mempertimbangkan kondisi yang diprediksi mempengaruhi keefektifan model yang digunakan. Untuk mendapatkan pembelajaran yang berkualitas, guru tidak cukup hanya memahami materi, tetapi juga mampu memilih model pembelajaran yang tepat.

Ekspositori sebagai model yang banyak digunakan guru adalah pembelajaran yang menekankan kepada proses penyampaian materi secara verbal dari guru kepada sekelompok siswa dengan maksud agar siswa dapat menguasai materi pelajaran. Model eksposistori memiliki sistem yang baik karena tersusun rapi, terjadwal dimulai dengan penyampaian materi melalui ceramah (Sanjaya, 2010). Suatu proses pembelajaran akan berhasil apabila ada keterlibatan siswa secara aktif yang akan memberi kemampuan mencari dan menemukan informasi dan solusi untuk permasalahan yang dihadapi. Pembelajaran berbasis masalah (Problem Based Learning) disingkat PBL, merupakan salah satu model pembelajaran inovatif yang dapat memberikan kondisi belajar aktif kepada peserta didik. PBL adalah suatu pendekatan pembelajaran yang menggunakan masalah dunia nyata sebagai suatu konteks bagi peserta didik untuk belajar tentang cara berpikir kritis dan keterampilan pemecahan masalah, serta untuk memperoleh pengetahuan dan konsep yang esensial dari materi pelajaran. PBL bertujuan untuk membantu peserta didik mengembangkan keterampilan dan memecahkan masalah. Penggunaan PBL dalam pembelajaran menuntut kesiapan guru sebagai fasilitator sekaligus pembimbing. Siswa juga harus siap terlibat secara aktif dalam pembelajaran (Rusman, 2010: 247). Pembelajaran berbasis masalah memiliki beberapa keunggulan, yaitu: (1) teknik yang cukup bagus untuk lebih memahami isi pelajaran; (2) menantang kemampuan siswa serta memberikan kepuasan untuk mengemukakan pengetahuan baru; (3) membantu siswa mengaplikasikan pengetahuan untuk memahami masalah kehidupan nyata; (4) membantu siswa mengembangkan pengetahuan baru dan bertanggung jawab dalam pembelajaran; (5) mendorong siswa melakukan evaluasi sendiri baik terhadap hasil maupun prosesnya; (6) mengembangkan kemampuan berpikir kritis; (7) mengembangkan minat untuk terus menerus belajar.

Penelitian ini merupakan penerapan model pembelajaran berbasis masalah dalam pembelajaran instalasi penerangan listrik. Ada sejumlah masalah yang ditemukan sehingga diperlukan penggunaan model pembelajaran berbasis masalah, antara lain: hasil belajar di bawah standar yang ditentukan; kurangnya keterlibatan siswa dalam aktivitas belajar mengajar di kelas; pemilihan model pembelajaran yang kurang tepat. Yang menjadi pertanyaan atau rumusan masalah dalam penelitian ini ialah: "Apakah hasil belajar instalasi penerangan listrik bangunan sederhana siswa yang diajar dengan model pembelajaran berbasis masalah atau PBL (Problem Based Learning) lebih tinggi jika dibandingkan dengan siswa yang diajar dengan model pembelajaran Ekspositori. 


\section{KAJIAN PUSTAKA}

Belajar menunjuk pada apa yang harus dilakukan seseorang sebagai subjek yang menerima pelajaran (sasaran didik). Belajar adalah modifikasi kemampuan melalui pengalaman. Menurut pengertian ini, belajar merupakan suatu proses kegiatan, sedangkan mengajar menunjuk pada apa yang harus dilakukan guru. Dua konsep tersebut terpadu dalam satu kegiatan, manakala terjadi interaksi guru-siswa. Hasil belajar adalah hasil yang diperoleh seseorang setelah menempuh kegiatan belajar. Setiap kegiatan belajar akan menghasilkan prestasi belajar, berupa perilaku-perilaku, yang oleh Bloom dikelompokkan ke dalam ranah kognitif, afektif dan psikomotor. Menurut Makmun seperti dikutip Mulyasa (2013), ciri-ciri perubahan perilaku hasil belajar adalah bersifat intensional, positif, dan efektif. Hasil belajar tampak sebagai terjadinya perubahan tingkah laku yang dapat diamati dan diukur. Perubahan tesebut dapat diartikan terjadinya peningkatan dan pengembangan yang lebih baik dibandingkan dengan sebelumnya. Hasil belajar merupakan hal yang dapat dipandang dari dua sisi yaitu sisi siswa dan dari sisi guru. Dari sisi siswa, hasil belajar merupakan tingkat perkembangan mental yang lebih baik dari sebelumnya. Pingkat perkembangan mental tersebut terwujud pada jenis-jenis ranah kognitif, afektif dan psikomotorik. Dari sisi guru, hasil belajar merupakan saat terselesaikannya bahan pelajaran (Dimyati dan Mudjiono 2009). Ada tiga macam hasil belajar, yakni (a) keterampilan dan kebiasaan, (b) pengetahuan dan pengertian, (c) sikap dan cita-cita, yang masing-masing golongan dapat diisi dengan bahan yang ditetapkan dalam kurikulum (Sudjana, 2008).

Hasil belajar dipengaruhi oleh (1) faktor internal yaitu individu meliputi faktor jasmaniah (kesehatan dan cacat tubuh), faktor psikologis (intelegensi, perhatian, minat, bakat, motif, kematangan dan kelelahan); (2) faktor eksternal meliputi: faktor keluarga (cara orang tua mendidik, relasi antar anggota kelurga, suasana rumah, keadaan ekonomi keluarga, pengertian orang tua, latar belakang kebudayaan); faktor sekolah (metode mengajar, kurikulum, relasi antara guru dan siswa relasi antar siswa, disiplin sekolah, pelajaran, waktu, standar pelajaran, keadaan gedung, metode belajar dan tugas rumah); faktor masyarakat (kegiatan siswa dalam masyarakat, teman bergaul, bentuk kehidupan dalam msyarakat, media massa); (3) faktor pendekatan belajar yaitu segala cara atau strategi yang digunakan siswa dalam menunjang efektifitas dan efisiensi proses pembelajaran.

Model pembelajaran adalah suatu desain yang menggambarkan proses rincian dan penciptaan situasi lingkungan yang memungkinkan siswa berinteraksi sehingga terjadi perubahan atau perkembangan pada diri siswa. Model-model pembelajaran dapat diklasifikan berdasarkan tujuan pembelajarannya, sintaks (pola urutannya) dan sifat lingkungan belajarnya.

\section{Pembelajaran Berbasis Masalah} (PBL) adalah inovasi dalam pembelajaran karena kemampuan berpikir siswa betulbetul dioptimalkan melalui proses kerja kelompok atau tim yang sistematis, sehingga siswa dapat memberdayakan, mengasah, menguji, dan mengembangkan kemampuan berpikir secara berkesinambungan (Rusman, 2010: 229). Tujuan pembelajaran berbasis masalah adalah penguasaan isi belajar dari disiplin heuristic dan pengembangan keterampilan pemecahan masalah. PBL juga berhubungan dengan belajar tentang kehidupan yang lebih luas (lifewide learning), keterampilan memaknai informasi, kolaboratif dan belajar tim, dan keterampilan berpikir reflektif dan evaluatif. PBL memiliki sejumlah karakteristik, antara lain: 
permasalahan menjadi starting point dalam belajar; permasalahan diangkat dari dunia nyata yang tidak terstruktur; permasalaahan membutuhkan perspektif ganda; permasalahan menantang pengetahuan, sikap, dan kompetensi yang kemudian membutuhkan identifikasi kebutuhan belajar.

Penerapan PBL didasarkan pada sejumlah pertimbangan antara lain guru menginginkan siswa tidak hanya sekedar dapat mengingat materi pelajaran, akan tetapi menguasai dan memahami secara penuh; guru bermaksud mengembangkan keterampilan berpikir rasional siswa; guru menginginkan kemampuan siswa untuk memecahkan masalah; guru ingin mendorong siswa lebih bertanggung jawab dalam belajarnya; guru ingin siswa memahami hubungan antara apa yang dipelajari dengan kenyataan dalam kehidupannya (Sanjaya,2010). Lebih lanjut dikatakan PBL memiliki sejumlah keunggulan antara lain: merupakan teknik yang cukup bagus untuk lebih memahami isi pelajaran; menantang kemampuan siswa serta memberikan kepuasan untuk menemukan pengetahuan baru; membantu siswa mengaplikasikan pengetahuan mereka memahami masalah dalam kehidupan nyata; membantu siswa mengembangkan pengetahuan baru dan bertanggung jawab dalam pembelajaran yang mereka lakukan; mendorong siswa melakukan evaluasi sendiri terhadap hasil maupun prosesnya; dapat mengembangkan kemampuan berpikir kritis; dapat mengembangkan minat belajar terus menerus. PBL juga memiliki kelemahan antara lain manakala siswa tidak memiliki minat maka akan merasa enggan untuk mencoba; membutuhkan waktu cukup lama untuk persiapan; tanpa pemahaman mengapa memecahkan masalah maka tidak akan belajar apa yang ingin dipelajari. Pembelajaran berbasis masalah atau PBL dilaksanakan dalam lima fase (sintaks), sebagaimana dikemukakan Arends (2011) yaitu: Fase 1. Orientasi siswa terhadap masalah autentik; Fase2. Mengorganisasikan siswa dalam belajar; Fase 3. Membantu siswa secara individual atau kelompok dalam melaksanakan penelitian; Fase 4. Mengembangkan dan menyajikan hasil karya; dan Fase 5. Analisis dan evaluasi proses pemecahan masalah.

Ekspositori adalah model yang menekankan pada proses penyampaian materi secara verbal dari seorang guru kepada sekelompok siswa dengan maksud agar siswa dapat menguasai materi secara optimal. Roy Killen seperti dikutip Sanjaya, (2010: 179) menamakan model ekspositori dengan istilah model pembelajaran langsung (direct instruction), karena materi pelajaran disampaikan secara langsung oleh guru. Siswa tidak dituntut menemukan karena materi pelajaran tersebut seakan-akan sudah jadi. Dengan kata lain, model ekspositori lebih menekankan proses bertutur yang baik dengan harapan siswa dapat memahami materi yang diajarkan oleh guru sebagai satusatunya sumber belajar. Pembelajaran ekspositori dipengaruhi aliran psikologi belajar behavioristik, yang lebih menekankan pada pemahaman bahwa perilaku manusia pada dasarnya adalah keterkaitan antara stimulus dan respon. Dalam implementasinya peran guru sebagai pemberi stimulus merupakan faktor yang sangat penting. Model pembelajaran ekspositori merupakan pendekatan pembelajaran yang berorientasi kepada guru (teacher centered approach). Guru memegang peranan yang sangat dominan dan cenderung menentukan segalanya. Melalui model ekspositori guru menyampaikan materi pelajaran secara terstruktur dengan harapan materi dikuasai siswa dengan baik.

Terdapat beberapa ciri model ekspositori yaitu: (1) dilakukan dengan cara 
menyampaikan materi pelajaran secara verbal; (2) materi pelajaran yang digunakan adalah yang sudah jadi, seperti data, fakta, konsep-konsep tertentu yang harus dihafal sehingga kurang menuntut siswa memikirkan atau mengkaji ulang; (3) tujuan utama pembelajaran adalah penguasaan materi itu sendiri, artinya setelah proses pembelajaran berakhir siswa diharapkan memahami materi pelajaran dengan benar (Sanjaya 2010: 177). Model ini kurang memberikan keluwesan bagi siswa mengikuti pembelajaran sesuai kemampuan sehingga siswa menjadi bosan dan tidak memperoleh hasil maksimal. Dapat dikatakan bahwa ekspositori adalah model pembelajaran yang kegiatan belajarnya didominasi dan cenderung berpusat pada guru, siswa hanya menunggu dan menerima dan tidak dituntut aktif dalam pembelajaran.

Uraian yang telah dikemukakan tentang model pembelajaran berbasis masalah dan model ekspositori menunjukkan adanya perbedaan dalam prinsip dan pelaksanaan kedua model tersebut. Adanya perbedaan di antara keduanya akan memberikan hasil belajar yang berbeda pula. Beberapa hasil penelitian terdahulu menunjukkan adanya perbedaan hasil belajar antara yang menggunakan pembelajaran berbasis masalah dengan yang menggunakan pembelajaran ekspositori. Rewidah Manik menemukan bahwa terdapat perbedaan yang sangat signifikan hasil belajar biologi antara yang menggunakan model pembelajaran berbasis masalah dengan yang menggunakan model eksposistori. Hasil belajar pada model pembelajaran berbasis masalah memiliki rata-rata 26,32 sedangkan dengan menggunakan model pembelajaran eksposistori memiliki rata-rata sebesar 24,96. Penelitian Gresya Hutabarat di SMA Negeri 3 Medan menemukan rata-rata hasil belajar kimia siswa yang diajar dengan model pembelajaran berbasis masalah lebih tinggi dari siswa yang diajar dengan model pembelajaran konvensional yaitu 92,85 dan 74,81 .
Dari berbagai uraian yang telah dikemukakan, terlihat nyata perbedaan di antara kedua pembelajaran ini yaitu terletak pada cara pengajarannya. Pada pembelajaran berbasis masalah, siswa mencari dan menemukan sendiri materi pembelajaran yang diberikan sehingga terlibat dalam proses pembelajaran. Siswa terlibat aktif dalam pembelajaran dan sehingga lebih memahami materi yang dipelajari. Pembelajaran berbasis masalah menuntut kesiapan guru sebagai fasilitator sekaligus pembimbing yang mampu merangsang kemampuan berpikir siswa. Pembelajaran ekspositori menuntut guru yang berperan aktif, sedangkan siswa cenderung pasif dan menerima ajaran yang disampaikan guru.

Dengan pembelajaran berbasis masalah para siswa terlibat aktif dalam kegiatan belajar melalui pemecahan masalah. Sebaliknya pada pembelajaran ekspositori, para siswa hanya menerima secara pasif apa yang disampaikan kuru. Hal tersebut akan berakibat pada perbedaan hasil belajar yang diperoleh kelompok siswa pada kedua model pembelajaran. Pada pembelajaran berbasis masalah siswa lebih banyak terlibat dalam aktifitas belajar sedangkan pada pembelajaran ekspositori siswa cenderung bersifat pasif, mengakibatkan hasil belajar siswa pada pembelajaran bernasis masalah lebih baik dari siswa pada pembelajaran ekspositori. Dengan demikian hipotesis penelitian adalah "hasil belajar siswa yang diajar dengan model pembelajaran berbasis masalah lebih tinggi jika dibandingkan dengan siswa yang diajar dengan model pembelajaran ekspositori pada mata pelajaran instalasi penerangan listrik bangunan sederhana".

\section{METODE PENELITIAN}

Penelitian dilaksanakan di SMK Negeri 2 Siatas Barita Tapanuli Utara. Subjek penelitian ialah siswa kelas XI Program Keahlian Teknik Instalasi Tenaga Listrik Tahun pelajaran 2014/2015 yang terdiri atas dua kelas. Melalui pengundian ditetapkan kelas XI TITL $_{1}$ dengan 28 siswa sebagai kelas kontrol; dan kelas XI $\mathrm{TITL}_{2}$ 
dengan 30 siswa sebagai kelas eksperimen. Metode penelitian adalah eksperimen dengan rancangan post test only control group design (Isaac dan Michael, 1982: 69). Kelas eksperimen diberi pembelajaran dengan model pembelajaran berbasis masalah sedangkan kelas kontrol diberi pembelajaran dengan model ekspositori. Dalam pelaksanaan eksperimen dilakukan pengontrolan yang meliputi: (1) materi yang diberikan pada kelas eksperimen dan kelas kontrol adalah sama; (2) guru yang mengajar memiliki kemampuan sama; (3) kelengkapan pembelajaran pada kedua kelas subjek penelitian sama.

Pada akhir eksperimen diadakan tes untuk mengukur hasil belajar menggunakan tes bebentuk pilihan berganda. Alat tes digunakan setelah melalui ujicoba untuk mengetahui validitas dan reliabilitas tes tersebut. Tes yang digunakan terdiri atas 22 butir tes yang valid dengan reliabilitas sebesar 0,703 (kategori tinggi).

Data hasil penelitian dianalisis dengan menggunakan statistik deskriptif untuk mendeskripsikan data, sedangkan untuk menguji hipotesis digunakan teknik analisis statistik uji-t. Penggunaan analisis statistik uji-t dilakukan setelah uji persyaratan analisis terpenuhi. Uji persyaratan analisis terdiri atas uji normalitas dengan menggunakan uji Liliefors, dan uji homogenitas dengan uji perbandingan varians terbesar dengan varians terkecil (uji F).

\section{HASIL DAN PEMBAHASAN}

\section{Hasil Penelitian}

Hasil deskripsi data pada kelas eksperimen dengan subjek penelitian sebanyak 30 terdapat skor tertinggi 19 dan skor terendah adalah 12 dengan rata-rata skor adalah 15,94. Karena rata-rata skor ideal $\left(\mathrm{M}_{\mathrm{i}}\right)$ dan standar deviasi ideal $\left(\mathrm{SD}_{\mathrm{i}}\right)$ masingmasing adalah 11 dan 3,66 maka rata-rata hasil belajar kelas eksperimen lebih tinggi dari rata-rata ideal yaitu 15,94 > 11. Hasil belajar siswa pada kelas eksperimen yaitu siswa yang diajar dengan model pembelajaran berbasis masalah dikategorikan menjadi empat kategori seperti disajikan dalam tabel 1.

Tabel 1 Kategori Hasil Belajar Kelas Eksperimen

\begin{tabular}{|l|c|c|c|}
\hline Kategori & Interval & $\begin{array}{c}\text { Frekwensi } \\
\text { Absolut }\end{array}$ & $\begin{array}{c}\text { Frekensi } \\
\text { Relatif (\%) }\end{array}$ \\
\hline Tinggi & $16,49<\mathrm{x}$ & 10 & 33.33 \\
\hline Cukup & $\begin{array}{c}11 \leq \mathrm{x} \\
<16,49\end{array}$ & 20 & 66.67 \\
\hline Kurang & $\begin{array}{c}5,51 \leq \mathrm{x}< \\
11\end{array}$ & 0 & 0 \\
\hline Rendah & $\mathrm{x}<5,51$ & 0 & 0 \\
\hline \multicolumn{2}{|c|}{$\mathbf{J} \mathbf{~ u ~ m ~ \mathbf { ~ a ~ h ~ }}$} & 30 & 100 \\
\hline
\end{tabular}

Pada kelas kontrol dengan subjek penelitian sebanyak 28 terdapat skor tertinggi adalah 19 dan skor terendah adalah 11 dengan rata-rata skor adalah 13, 86 dan standar deviasi 1,89. Rata-rata hasil belajar hasil belajar kelas kontrol lebih tinggi dari rata-rata ideal yaitu 13,86 > 11. Kategori hasil belajar kelas kontrol, yaitu siswa yang diajar dengan model pembelajaran ekspositori disajikan dalam tabel 2 .

\section{Tabel 2 Kategori Hasil Belajar Kelas}

\section{Kontrol}

\begin{tabular}{|c|c|c|c|}
\hline Kategori & Interval & $\begin{array}{c}\text { Frekwensi } \\
\text { Absolut }\end{array}$ & $\begin{array}{c}\text { Frekensi } \\
\text { Relatif }(\%)\end{array}$ \\
\hline Tinggi & $16,49<x$ & 3 & 10,71 \\
\hline Cukup & $\begin{array}{c}11 \leq x \\
<16,49\end{array}$ & 25 & 89,29 \\
\hline Kurang & $\begin{array}{c}5,51 \leq \mathrm{x}< \\
11\end{array}$ & 0 & 0 \\
\hline Rendah & $x<5,51$ & 0 & 0 \\
\hline \multicolumn{2}{|c|}{$\mathbf{J} \mathbf{u} \mathbf{~ m} \mathbf{l}$ a h } & 28 & 28 \\
\hline
\end{tabular}

Hasil uji normalitas data kelas eksperimen dan kelas kontrol dengan menggunakan uji Liliefors disajikan pada tabel 3 yang menunjukkan bahwa data hasil penelitian pada kedua kelas subjek penelitian berdistribusi normal.. 
Tabel 3. Ringkasan Hasil Uji Normalitas Data Penelitian

\begin{tabular}{|l|c|c|c|c|}
\hline \multicolumn{1}{|c|}{ Kelas } & $\mathrm{L}_{\text {hitung }}$ & $\mathrm{A}$ & $\mathrm{L}_{\text {tabell }}$ & $\begin{array}{c}\text { Sim } \\
\text { pulan }\end{array}$ \\
\hline Eksperimen & $\mathbf{0 , 1 3 4}$ & $5 \%$ & $\mathbf{0 , 1 6 1}$ & Normal \\
\hline Kontrol & $\mathbf{0 , 1 5 1}$ & $\mathbf{5 \%}$ & $\mathbf{0 , 1 6 7}$ & Normal \\
\hline
\end{tabular}

Untuk uji homogenitas varians data digunakan uji perbandingan varians terbesar dengan varians terkecil. Ringkasan hasil uji homogenitas ditunjukkan pada tabel 4 .

Tabel 4. Ringkasan Hasil Uji Homogenitas Data Penelitian

\begin{tabular}{|l|c|c|c|c|c|c|}
\hline elas & $\mathbf{n}$ & $\mathbf{S}^{2}$ & $\mathbf{F}_{\text {hitung }}$ & $\boldsymbol{\alpha}$ & $\mathbf{F}_{\text {tabel }}$ & $\begin{array}{c}\text { Kesim- } \\
\text { pulan }\end{array}$ \\
\hline $\begin{array}{l}\text { Eksperi- } \\
\text { men }\end{array}$ & 30 & 3,167 & 1,13 & $5 \%$ & 1,86 & Homogen \\
\hline
\end{tabular}

Nilai statistik uji-t dihitung secara manual dengan bantuan program komputer Microsoft Excel 2007. Hasil perhitungan adalah $\mathbf{t}=16,39$. Harga $\mathbf{t}$ pada tabel dengan $\mathrm{dk}=56$ dan $\alpha=0,05$ adalah 2,003. Dari hasil ini diperoleh bahwa t-hitung > t-tabel yang berarti bahwa skor rata-rata hasil belajar kelas eksperimen lebih tinggi dari skor kelas kontrol pada taraf signifikansi 95\% ( $\alpha=$ $0,05)$. Ini berarti bahwa hipotesis penelitian yaitu "hasil belajar siswa yang diajar dengan model pembelajaran berbasis masalah lebih tinggi jika dibandingkan dengan hasil belajar siswa yang diajar dengan menggunakan model pembelajaran ekspositori pada mata pelajaran instalasi penerangan listrik bangunan sederhana", dapat diterima.

\section{Pembahasan Hasil Penelitian}

Dari hasil analisis data secara deskriptif ditemukan bahwa hasil belajar pada kedua kelompok subjek penelitian cenderung tinggi. Hal ini dilihat dari skor rata-rata hasil belajar pada pada kedua kelompok yang lebih besar dari rata-rata skor ideal. Selanjutnya hasil belajar pada kedua kelas dibandingkan satu sama lain untuk melihat perbedaan di antara keduanya. Ratarata hasil belajar dengan model pembelajaran berbasis masalah lebih tinggi dibandingkan dengan model ekspositori yaitu 15,93 > 13,85. Perbedaan ini diuji dengan analisis statistik. Hasil analisis menemukan perbedaan yang signifikan di antara kedua model pembelajaran. Analisis statistik uji t menghasilkan nilai $\mathbf{t}_{\text {hitung }}$ sebesar 16,3861. Karena nilai t pada tabel untuk $\alpha=0,05$ dengan derajat kebebasan 56 adalah 2,003, berarti rata-rata hasil belajar kelas yang diajar dengan model pembelajaran berbasis masalah lebih tinggi dibandingkan kelas yang diajar dengan model ekspositori. Hasil ini menegaskan bahwa dalam pembelajaran instalasi penerangan listrik bangunan sederhana, hasil belajar dengan menggunakan model pembelajaran berbasis masalah lebih baik dibandingkan hasil dengan model ekspositori. Kenyataan ini menunjukkan bahwa penggunaan model pembelajaran berbasis masalah berpengaruh kepada meningkatnya hasil belajar instalasi penerangan listrik bangunan sederhana. Dikatakan demikian karena siswa yang belajar dengan model pembelajaran berbasis masalah memperoleh hasil yang lebih tinggi dibandingkan siswa dengan model ekspositori, sedangkan model pembelajaran yang secara umum digunakan adalah model ekspositori.

Pembelajaran berbasis masalah sebagai model yang dirancang untuk mengaktifkan siswa menekankan pembelajaran siswa aktif dengan suasana yang positif, yaitu setiap siswa dituntut untuk saling membantu dan saling membelajarkan. Penggunaan model pembelajaran berbasis masalah akan menarik dan dapat mengembangkan potensi peserta didik. Berbeda dengan model pembelajaran berbasis masalah, pada model ekspositori, 
pusat (sentral) pembelajaran adalah guru yang hanya menerangkan tanpa mengetahui apakah siswa benar-benar mengerti atau memahami apa yang diajarkan. Pembelajaran terjadi satu arah dari guru ke siswa tanpa ada umpan balik yang berarti dari siswa. Dalam pembelajaran ekspositori kegiatan yang terjadi hanya transfer pengetahuan, informasi, nilai dan lain-lainnya yang disampaikan secara lisan dari guru kepada siswa.

Perbedaan pola pada kedua model ini pada akhirnya mengakibatkan perbedaan pada hasil belajar yang signifikan pada kedua kelompok siswa. Kelompok siswa pada model pembelajaran berbasis masalah terlibat secara aktif melakukan berbagai kegiatan belajar dan pemecahan masalah, sedangkan pada ekspositori siswa cenderung bersifat menerima. Hal ini berakibat pada hasil yang didapat hanya tergantung pada apa yang disajikan guru. Dapat dipahami bahwa siswa yang secara aktif terlibat dalam kegiatan belajar akan mendapatkan hasil yang lebih baik daripada siswa yang hanya menerima secara pasif.

Dalam penelitian ini ditemukan siswa yang belajar dengan model pembelajaran berbasis masalah memperoleh hasil belajar yang lebih baik dibandingkan siswa yang belajar dengan model ekspositori. Perbedaan hasil belajar tersebut tentunya diakibatkan kegiatan pembelajaran yang berbeda. Oleh karena itu dapat dikatakan bahwa pengaruh penggunaan model pembelajaran berbasis masalah terhadap hasil belajar instalasi penerangan listrik bangunan sederhana, ialah bahwa hasil belajar siswa dengan pembelajaran berbasis masalah lebih baik dari siswa dengan model ekspositori. Perbedaan yang ditemukan sangat mungkin dipengaruhi faktor lain selain model pembelajaran. Beberapa faktor yang tidak dapat dikontrol yang bisa mempengaruhi hasil antara lain interaksi di antara sesama kelompok subjek maupun interaksi dengan dunia luar.

\section{KESIMPULAN}

Dari hasil penelitian dsimpulkan halhal sebagai berikut: (1) hasil belajar instalasi penerangan listrik bangunan sederhana siswa yang diajar dengan menggunakan model pembelajaran berbasis masalah cenderung tinggi; (2) hasil belajar instalasi penerangan listrik bangunan sederhana siswa yang diajar dengan menggunakan model pembelajaran ekspositori cenderung tinggi; (3) hasil belajar instalasi penerangan listrik bangunan sederhana siswa yang diajar dengan model pembelajaran berbasis masalah, lebih tinggi jika dibandingkan dengan hasil belajar siswa yang diajar dengan model ekspositori.

Berdasarkan hasil dan kesimpulaan disarankan hal-hal sebagai berikut: (1) para guru dapat menjadikan model pembelajran berbasis masalah sebagai salah satu alternatif dalam untuk meningkatkan hasil belajar instalasi penerangan listrik bangunan sederhana; (2) kepada para peneliti berikutnya agar mengadakan penelitian yang sama pada kelpok subjek maupun topik yang berbeda.

\section{DAFTAR PUSTAKA}

Arends, Richard I. (2012). Learning To Teach 9th eds. New York: McGraw Hill.

Arikunto Suharsimi. 2006. Prosedur Penelitian. Jakarta : Rineka Cipta

Arikunto Suharsimi,2009. Dasar-dasar Evaluasi Pendidikan,Jakarta : Bumi Aksara

Hutabarat, Gresya. 2014. Pengaruh Model Pembelajaran Berbasis Masalah Terhadap Hasil Belajar Siswa. Skripsi. Medan: FMIPA-UNIMED

Isaac, Stephen dan Michael, William B. (1982). Handbook In Research And Evaluation. San Diego: EdITS publishers. 
Manik, Rewidah.2014. Penerapan Model

Pembelajaran Berdasarkan Masalah

(Problem Based Learning)

BerbasisKurikulum 2013Untuk

Meningkatkan Hasil Belajar Siswa.

Skripsi. Medan: FMIPA UNIMED.

Rusman. 2010. Model-ModelPembelajaran. Jakarta : Rajawali Pers

Sanjaya,Wina. 2010. Strategi Pembelajaran

Berorientasi Standar Proses

Pendidikan Jakarta: Kencana

Prenada Media Group

Slameto. 2003. Belajar dan Faktor-faktor yang Mempengaruhi. Jakarta: Rineka Cipta

Sudjana, N. 2008. Penilaian Hasil Proses

Belajar Mengajar. Bandung:

Tarsito.

Sudjana. 2002. Metoda Statistika.Bandung:

PT.Tarsito

Trianto.2012. Mendesain Model

Pembelajaran Inovatif-Progresif.

Jakarta : Kencana 